\title{
Developing of Human Resources in E-learning and Practical Experience in its implementation
}

\author{
Tamar Gogoladze, Natia Zhozhuashvili, Elene Khojevanishvili, Ana Tsiklauri \\ 1tamilagogoladze@gmail.com; 2natia7413@gmail.com; ${ }^{3}$ ekhojevanishvili@gmail.com; \\ ${ }^{4}$ ana.tsiklauri@gmail.com
}

\begin{abstract}
The article deals with practical experience in developing and implementing human resources in Elearning in Gori State teaching University.

German International cooperation civil organization (GIZ) contributed greatly the development of electronic learning sphere during a 7-year cooperation with Georgia. The working groups sent from Gori State teaching University after completion the full course of trainings and getting certificates initiated implementing the project "The Development of Human Recourses for implementation of Elearning" and planned to hold various activities within the project, also the research for finding out the readiness for implementing the innovation was held. The results got by the feedback clarified that the professors and teachers of the University share the necessity of implementing e-learning in the teaching process as an assisting tool and express their readiness for preparation pilot programs. After competition of the full training course (4 modules) the $y$ presented presentations in 10 different disciplines which were greatly approved by GIZ experts. The project participants and leaders made further plans for implementation and development of E-learning.

For the country like Georgia, it is important to raise the competences and skills of professors and teachers and mobilize all the resources to meet the challenges of the epoch.
\end{abstract}

\section{Introduction}

The availability of computer and internet access in the XXI century enabled modern methodology to use online learning widely. E-learning system is a good example of this, using information and electronic technologies where "multimedia design" plays an important role.

According to R.Mayer "multimedia design" enables perception of material by a human when it is presented by texts and illustrations, it is concentrated on continuity, it is modal, it has outlined structure (with titles and sub-subtitles). Besides, it should also be taken into consideration that such learning should meet student's needs, expectations, possibilities, it should develop the skills and competences that will answer modern challenges, reduce expenses and maintain personal freedom. Besides the applicants for studying at universities it should also meet the Andragogy needs that is- it should be available to the people seeking job or attempting to get a higher position. According to one of the strategies e-learning is considered as an instrument based on knowledge, for creating dynamic, competitive economics and creating lifelong learning space.

The world industry of E-learning is about 48 milliard dollars. It was created as a result of developing internet and multimedia. Electronic learning is the usage of communicative technologies and internet in teaching process as an assisting instrument for filling and not substituting traditional 
learning. The implementation of the e-learning component aims rising teaching quality and increasing its affectivity. Its key moments are consulting, content, technologies, service and support and it should be taken into consideration that "virtual model"appeared to be more competitive than other forms of teaching and became a main tool in modernizing of education in many countries of the world and among them it aroused interest in Georgia as well. Nowadays teachers, program providers and teaching developers are the interested part who realizes that exchange of information by means of communicative net is very important for affective teaching.

\section{Implementation}

German International cooperation civil organization (GIZ) contributed greatly the development of electronic learning sphere during the 6-year cooperation with Georgia. The working groups sent from almost every important Universities of Georgia, separate ministries, various organizations and vocational schools attended general practical course offered by $\mathrm{ClZ}$ and as a result of those trainings several (more than ten) pilot programs were created.

A group of professors sent from Gori State Teaching University -T. Gogoladze, E. Khojevanishvili, N. Zhozhuashvili and the main specialist of Information technologies support service-A. Tsiklauriparticipated in the training program "The Development of Human Resources and Institutional Building for Electronic Learning in the South Caucasus" organized by GIZ (Elke Vemhoff-Project Manager, Irakli Shurghaia - a coordinator in Georgia). Our involvement in acquiring e-learning principles was conditioned by general and concrete circumstances existed in our higher educational institution.

The training organized by GIZ was held in two parts-in face to face and online regimes. The program consisted of four modules (e-learning management in practice, didactic methodology/instructive design, creating teaching materials and mentor), which were led by certified trainers trained by GIZ. At the training a few factors sprang out, namely, e-learning is a constituent part of Bologna process and a form of student oriented teaching, its motto is "learn whatever you wish, whenever you wish and wherever you wish". Also it was mentioned that leading Universities of Europe and USA have been using e-learning for a long time as an assistant tool and a lively alternative of a traditional learning process and that is why, nowadays the majority of Universities of the world use this method successfully. In France, Finland, South Korea, USA, Great Britain, New Zeeland, Canada and other countries e-learning became practice of everyday educational and labor affairs.

Also the priorities of electronic learning were outlined: free option of time and space, flexible learning conditions, possibility of working in asynchrony format; diversity of materials-video, audio, multimedia or the usage of some other teaching complex elements enables us to make academic process more effective, creative and inclusive, substitution of teaching forms make us avoid routine and increases student's interest and motivation; Constant complement-renovation of materials and possibility of making needy changes enables us 1 . To use many times once created material 2 . To meet the demandsE-learning course. It gives possibility to use the knowledge and experience of highly qualified personnel working in other companies. It is easy to use for training personnel working in different types of organizations. It is advantageous for continuous education. The monitoring of learning process is simplified and students' testing and evaluation system is perfected. It requires less financial needs. Once created course can be used during a long period simultaneously with several target groups.

On the basis of the information acquired at the trainings and taking into consideration the characteristics of e-learning our group presented a piloted course for the summing up meeting of 
Tamar Gogoladze, Natia Zhozhuashvili, Elene Khojevanishvili, Ana Tsiklauri; Developing of Human Resources in E-learning and Practical Experience in its implementation, Transactions on Networks and Communications, Volume 3 No 2, April (2015); pp: 128-133

the training: "Modern Georgian Language" which became a subject of interest and was worthy of the experts attention and after completion of the full course of the training the participants were awarded certificates of electronic learning specialists.

The training of GIZ attended by our group created and idea and motivation to prepare a project " The Development of Human Recourses for Implementation Electronic Learning" at Gory State teaching University with the assistance of GIZ trainers and relying on their experience. This project was carried out in May-June 2014 with active support of the Rector (Prof. G. Sosiashvili). (The Project manager - N. Zhozhuashvili, trainers-T.Gogoladze, E. Khojevanishvili and A. Tsiklauri.) For carrying out the project the following activities were held:

For the administration and professors of the University were held: 1. Presentation-summing "Electronic learning: goals and objectives", 2. Presentation- "The necessity of implementation of Elearning in Higher educational institutions", 3. Research for finding out the readiness for implementation of innovational learning, 4. Training-“Electronic learning: goals, objectives, implementation of innovational learning at educational institutions and getting to know with successful e-learning courses. (Professor Mariam Manjgaladze, GIZ e-learning center expert participated with the project working team).

After the mentioned work with the feedback it became clear that the usage of e-learning as an assistant tool of traditional education, will be acceptable for the participant professors and teachers and for this reason preparing electronic courses will be affective.

The answers to the following questions in percent are presented on the diagram 1.

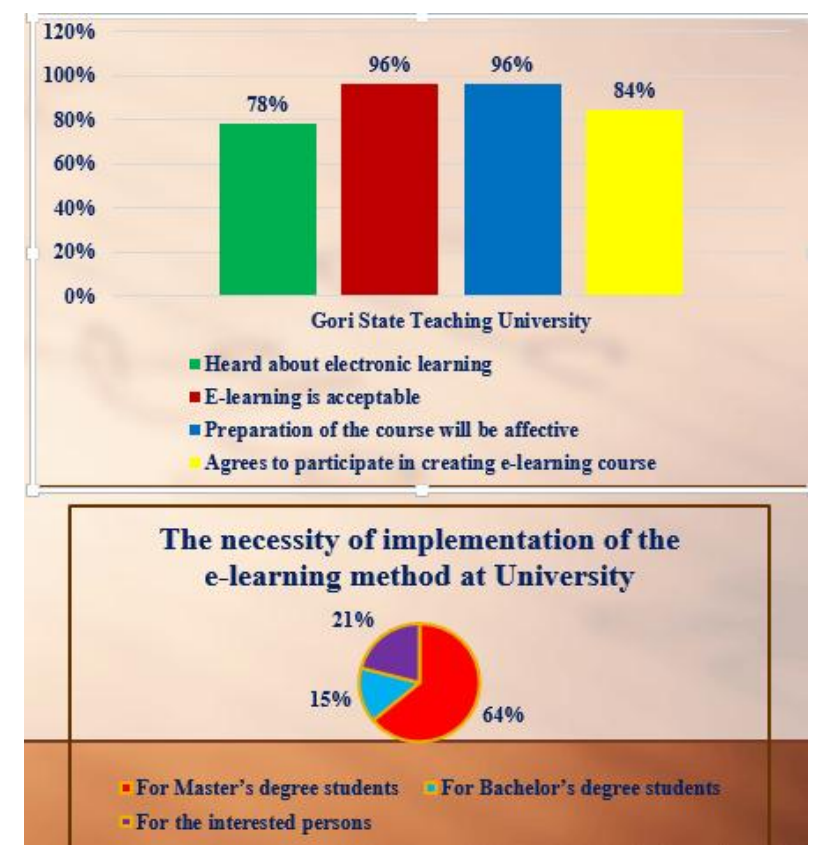

Figure 1

- Have you heard about electronic learning?

- At what rate will be acceptable for you the usage of e-learning as an assistant tool of the traditional education?

- What is your opinion -how affective will be preparing electronic courses in your subject?

- Do you agree your participation in creating electronic course? 
- In what perspective do you see the necessity of implementation of e-learning method at University?

That means that the research proved the readiness for preparing human resources for implementation of electronic learning.

The project aimed to prepare teachers and professors for creating electronic courses that on the next stage by implementing e-learning as an assistant tool of traditional academic process facilitate master's degree students and bachelor's degree students in academic process, to create for them more flexible learning environment with less expenses, with online communication to their mentors for consultations. In case of employment or some other extreme situations they will be able to acquire the planned material foreseen by the curriculum. They will be given possibility to prepare materials and homework, acquire knowledge and to get to know with scientific literature related to the given subject in the place and time available for them. By electronic courses they will be provided with materials enriched by more and more and diverse visual, audio-video materials. They will be able to control their own evaluation and finally on the basis of the gained knowledge pass final exams successfully and use the gained skills in their practical work.

The working schedule according to the modules was worked out:

1. Teaching methodology- the goals and objectives of teaching methodology (Preparation); objectives to be solved in the process of implementation and their correlation (implementation); evaluation of the courses and goals. Mentor and tutor; (T. Gogoladze)

2. Creating content (teaching materials) - the stages of implementation of teaching technologies and their meaning in educational institutions; the stages of creating content; (methodological viewpoints, target groups and work with them, reflexion connected to the teaching material, screen segmentation design, instruments for creating content); forming the structure and conception of the content- schematic frame in author program, the draft of schematic frame for programming, gathering material, technical issues; realization -creating teaching materials, interactive elements, content forming evaluation, packing, quality assurance, general instructions; interaction; self-evaluation-feedback; (E. Khojevanishvili)

3. Electronic learning Management - preparation: defining the goals and objectives of the project, forming the standard of the quality; (forming project team-distributing resources, preparing budget; time management-planning process and time; self-checking test); management in practice implementing; (control of goals, standards and budget; summing up test; following the settings of time); management in practice-packing; (measuring goal achievement; review of time management; evaluation of the usage of resources; calculating real expenses; preparation the next course; selfevaluation test; (NatiaZhozhuashvili)

4. Instruction design review of Caucasus-learning, the essence of Exe; creating design; questionnaire methods. (Exe program), self-evaluation methods (Exe program), uploading videoaudio materials (Exe program), glossary. (Ana Tsiklauri)

After carrying out the project the me members of the target team, the professors of various subjects presented prepared points and issues from the pilot electronic courses in History, in various subjects of Economy, Dialect study, Eco-tourism, Computing skills and Academic writing which were highly evaluated by specially invited International trainers -Maia Ninidze and Mariam Manjgaladze. They denoted that within the project great interest and readiness from Teachers and professors of the 
Tamar Gogoladze, Natia Zhozhuashvili, Elene Khojevanishvili, Ana Tsiklauri; Developing of Human Resources in E-learning and Practical Experience in its implementation, Transactions on Networks and Communications, Volume 3 No 2, April (2015); pp: 128-133

University for implementation innovated teaching methods was quite vivid and the result-the goal of the project-was impressive which clarifies once more the possibilities of online cooperation.

The pilot electronic courses presented within the project, in which Information-communication resources, texts, video-audio files, multimedia presentations, teaching websites/blogs were used, proved that the gained knowledge and skills will enable the members-the academic staff of the target team to implement electronic courses and e-learning in the nearest future. In the context of training the academic staff of the University in the sphere of e-learning, on the basis of the experience of other universities the courses on the topics such as individual online consultations, creating electronic dossiers and renewing, testing by means of net tools and others, will be implemented that will find positive reflection on the academic process. Creating e-learning center at the university, development of the infrastructure, technical and program maintenance will be inevitable. Diagram N2:

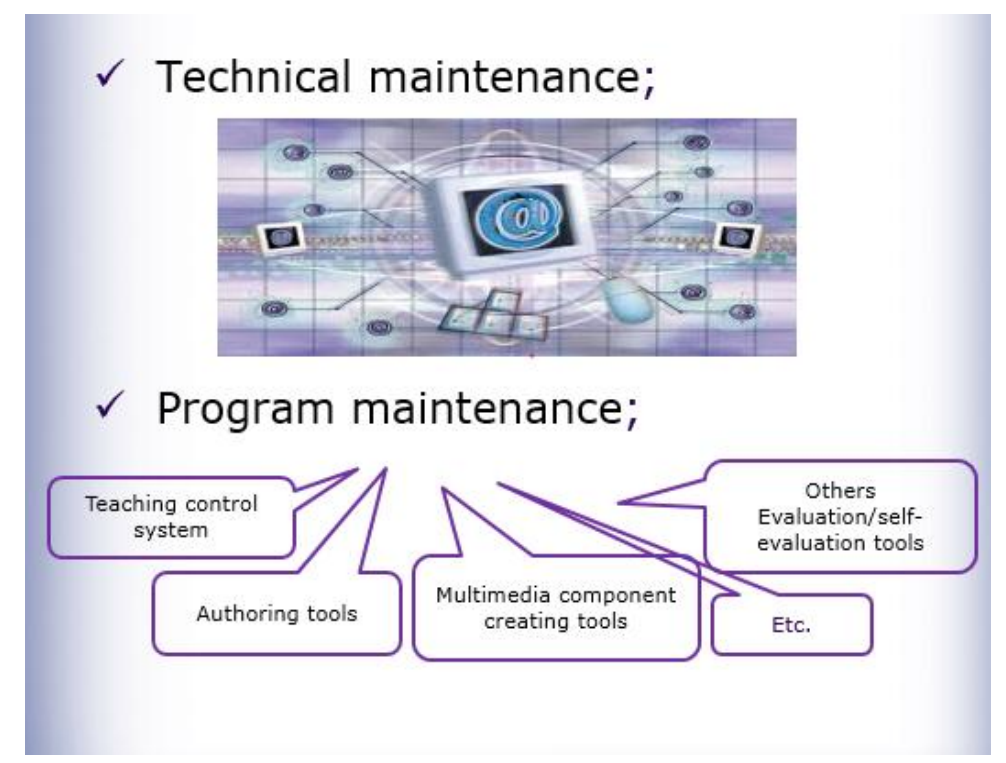

Figure 2

Nowadays, when the Ministry of education and Science is planning to widen teaching sphere by new media and cover the education system, the small country like Georgia, which is facing new challenges inevitably needs rising professors and teachers competences and mobilization of all the resources in order to meet the needs of the epoch honorably.

\section{REFERENCES}

[1] Mayer R.E. Multimedia Learning. Cambridge University Press. 2001.

[2] Mayer R. E., Moreno R. Nine ways to reduce cognitive load in multimedia learning, Educational psychologist. 38 (1), 2003.

[3] Najjar L. J. Multimedia information and learning, Journal of educational multimedia and hypermedia. 5(2), 1996. 
Transactions on Networks and Communications; Volume 3, Issue 2, April 2015

[4] Сатунина А. Е., Информационное обеспечение стратегических задач в области высшего образования с использованием ЭВМ, Передовой научный опыт высшей школы, рекомендуемый для внедрения. М., 1991. Вып. 2.

[5] Сатунина А. Е., Современное состояние и развитие правовой информатизации высшей школы. М., 1999.

[6] Сатунина А. Е., Сысоева Л. А., Финансы и статистика, Управление проектом корпоративной информационной системы предприятия. М., 2009.

[7] Полат Е.С., Бухаркина М.Ю., Моисеева М.В., Теориа и практика дистанционного обучения, М., 2004 